\title{
The System Saving Mechanism \\ in Russian Criminal Law: \\ Notion, Structure, Value
}

\author{
Anna V. Denisova* \\ Samara State University \\ 1 Ak. Pavlova Str., Samara, 443011, Russian
}

Received 05.09.2014, received in revised form 14.10.2014, accepted 02.11.2014

The paper deals with the features of the system saving mechanism functioning in criminal law; the detailed description of its structure and contents is given; this mechanism value for providing branch integrity is revealed. Due to this mechanism criminal law processes the branch system, makes its elements consistent and coherent. Such structural elements as the principles, purposes and tasks of criminal law, branch presumptions and fictions, prejudices, lacunes and conflict rules are carefully investigated in the paper. The author draws the conclusion that the studied mechanism is one of the means of self-regulation in criminal law.

Keywords: systemacity of law, criminal law, system saving mechanism, principles, purposes and tasks of criminal law, legal presumptions and fictions, prejudices, lacunes and conflict rules.

Research area: law.

It is necessary to understand that the modern criminal law is not only a set of laws and institutions, not only a standard organization, but a legal phenomenon which includes 1) criminal law as a difficult system organization formed by the standard instructions and contained in legal acts as the sources of criminal law; 2) the legal institutions consisting of the criminal law and standard instructions repeated in them; 3) authorized sources of criminal law; 4) the criminal and legal relations of guarding, precautionary and regulatory character.

This list is not comprehensive, because there is a particular phenomenon in the system of criminal law that unites all aforesaid elements and provides their effective coexistence and interaction. This integrating legal phenomenon is a so-called system saving mechanism, the one that provides integrity, systemacity and the coordination of all branch elements interaction in criminal law. It also regulates influence of external conditions on criminal law via providing continuity and variability combination in the process of criminal law regulation.

Due to this mechanism a certain ordering impact on the branch components is carried out, their joint functioning is coordinated and the timely adaptation of branch to the social changing is provided. The structure of the system saving mechanism includes the following

(C) Siberian Federal University. All rights reserved

* Corresponding author E-mail address: anden@front.ru 
legal components as principles, purposes and problems of the criminal law, presumption and fiction, estoppels, lacunes and collision rules, and this mechanism operates through system communications between above mentioned branch elements.

One of the most important elements of the system saving mechanism is the corresponding branch principles, certain ideas, which depend on a moral, political and economic condition of society and determine the lawmaking and law enforcement activity in criminal law [Lopashenko, p. 159; Mal'tsev, p. 94]. Five principles are consolidated in the existing criminal law: the principles of legality, equality of citizens before the law, fault, justice and humanity. In the doctrine of criminal law other principles of criminal law are distinguished; they are not consolidated at the legislative level. These are the principles of inevitability of responsibility and personal responsibility [Kudriavtsev, Naumov [et al.], p. 42; Inogamova-Khegai, p. 87].

The principles or the leading ideas give a notion about due processes in criminal law, they define what it has to be like; they are the essence of criminal law, these ideas-principles had appeared and developed long before criminal law itself and subsequently define its content. M.M. Bablaiev and Iu.E. Pudovochkin remark that the principles of criminal law carry out important protective stabilizing function: they act as a "filter" which passes into criminal law norms, corresponding to the branch principles, and also prevent introduction of branch elements incompatible with it, providing coherence and systemacity of criminal law, keeping its intrinsic properties [Babaiev, Pudovochkin, p. 7].

It is indisputable that the principles of criminal law are determined both as a system construction of this branch and as a realization of criminal law: principles of criminal law provide a uniform application of criminal law by the all subjects of law enforcement activity, they unify the law enforcement activity.

But their impact on the legislative activity is also significant. They influence the improvement of existing system of criminal law. By proclaiming the above ideas-principles the legislator assigns on certain duties to realize them in the criminal law. Having found any discrepancy to the existing criminal law, the legislator is obliged to eliminate the revealed defect of lawmaking activity by cancelling the corresponding norm or changing its contents bringing it in compliance with the broken branch principle. Legal practice has already had similar examples. In the case of M. A. Aslamazyian it was established by the constitutional court of the Russian Federation that "entering into the legal regulation of the standard situation which establishes the criminal responsibility for currency smuggling, which does not allow to delimit a crime from the similar one by the objective side of an administrative offense, the federal legislator -in defiance of the Constitution Russian Federation and the international obligations of the Russian Federation -creates the possibility of any application of this situation and inadmissible substitutions of administrative responsibility into the criminal law, which contradicts the conventional principles of criminal liability, principles of the criminal legislation, and also the principles of legality, equality of citizens before the law and court, justice, humanity, fixed on the basis of the Constitution of the Russian Federation and the Criminal Code of the Russian Federation (italics -A.D.), and it also does not correspond with the basis of criminal responsibility and the notion of crime ..." [On the case of...], therefore the content of the corresponding forbidding criminal law about commodity smuggling and application practice had significantly changed, and in a couple of years the p. 188 in the Criminal Code of the Russian Federation this was declared 
as invalid, and commodity smuggling was decriminalized. Thus, the principles of criminal law provide intra-branch unity and coherence by defining the contents and implementation of each criminal precept of law and institution, development of any criminal legal relations and content of all branch formal-legal sources, thereby this principles maintain the integrity of criminal law by being an integral part of its system saving mechanism.

The goals and objectives of branch are also a very important element of aforesaid mechanism, because the main characteristic of any system is its integrity, which is directly connected with the goals for which performance a system exists. If the goal is not specified in the explicit form (as we can observe in the Criminal Code of Russian Federation, where the tasks of the criminal legislation are only listed and not the branch goals), and a studied object has the complete characteristics, it is possible to define the goal or the manifestation which connects the goal with tools of its achievement (mainly it is objective functions) through studying of the emergence reasons of regularity of integrity. By dismembering the system, it is possible to analyze the emergence reasons of integrity on the basis of establishing relationships of cause and effect connections of various natures between parts, a part and the whole, identifications of the cause and effect conditionality of the whole by its environment. It is represented that the goal of branch of the law is a conceivable result of certain legal and other activity, result of functioning rules of law and others elements of branch system.

In our opinion, the main branch goals of criminal law is themaintenance of law enforcement in the country and beyond it, ensuring the criminal law means of safe coexistence of people in society (including admission of the social conflicts) that does not interfere in the allocation of the goals of this branch of law, which have a subordinated value in the relation to the aforesaid.

Thegoalachievementinvolvestheconsecutive solution of a number of interconnected tasks which a law branch faces, the problems which demand the solution; thus, objectives act as intermediate goals of law branch. Objectives of criminal law are determined in Part.1 Article. 2 in the Criminal Code of the Russian Federation ("the tasks of the present Code are as follows: the protection of the rights and freedoms of man and citizen, property, public order and public security, the environment, and the constitutional system of the Russian Federation against criminal encroachment, the maintenance of peace and security of mankind, and also the prevention of crimes"). Thus in special literature it is noted that from the last task one more directly follows -educational task [Naumov, p. 38; Kozachenko, p. 49].

The next important components of the system saving mechanism of criminal law are presumption and fiction. Traditionally, in the general theory of the law legal presumptions are defined as means of the legal equipment, which are acceptance of the facts, communications, phenomena, situations seen as truth, until the opposite is proved. It means in advance established by the law assumptions, which both law-enforcement bodies and citizens are obliged to accept without proofs until this assumption is disproved. Thus, in criminal law, presumption, as a rule, is assumption of existence or nonexistence of legally significant facts, which leads to criminal law relations' emergence (or on the contrary -stating impossibility of their emergence, such as, in a case of committed by the juvenile person of socially dangerous act, stated by the Criminal Code of Russian Federation acts (fixed in Article. 20 of the Criminal Code of Russian Federation presumption of juvenile's lack of understanding the danger of the action, determining all questions of juvenile 
criminal liability and corresponding procedural consequences. Due to presumption, separate facts of case which have legal meaning are specified and the criminal law assessment of actions is predetermined. Therefore, legal presumptions are necessary for coordination of judicial norms of both the same and different branch belonging, for stability assurance of criminal law system, for saving of time and amount of criminal influence means. This is the reason to accept presumptions as important components of system saving mechanism both as branch of criminal law and legal system.

In the general theory of law, it is a common understanding of legal fiction as something, which does not actually exist, but is accepted as existing by the legislation. Legal fiction is a special rule which dictates to consider the nonexistent as existent, and vice versa. Thus, the judged person after expunging a criminal code or removal of conviction ceases to be considered one, because due to provisions of Paragraph. 6 Article. 86 of the Criminal Code of Russian Federation, "expunging or striking of a criminal record shall annul all the legal consequences related to the record of conviction". In special literature other criminal fiction in concept of a crime, institution of recurrence crimes, formal structures, conditional condemnation, institution of releases from criminal liability and punishment are revealed and investigated [Pan'ko, p. 12-16]. We will specify that fictions are special legal means, the rules of giving the necessary visibility to legal reality, which are fixed in the text of criminal law sources and are legitimately realized in decisions of law-enforcement bodies. They differ from all other criminal law environment components in the specific contents; they order to consider the nonexistent facts as existent and vice versa. It means that fictions are a specific manifestation and supplement to the criminal law, they are a reasonable attempt of legal tools to go beyond itself, because in some cases there is a lack of giving a legal value to the nonexistent facts or deprivation of legal value to the existent for a comprehensive and complete criminal regulation, thereby, there is a specific processing of system content of criminal law, the necessary joint and harmonization of its elements are provided, it means that the necessary level of their intrabranch unity and integrity is supported. This is the reason to consider them as important system saving mechanism components as branches of criminal law, and as legal system.

The next functional link in the system saving mechanism of criminal law is prejudices. Traditionally under a notion of prejudices we understand the procedural category which means the question is predetermined in the sphere of judicial practice and important legal value of the previous judgment for the new process, the special proving rule [Skoblikov, $\mathrm{p}$. 69-80; Lazarev, p. 114-123; Komissarova et al]. However the notion of a prejudice has material understanding in criminal law, and as a rule, it is connected with existence of structures of crimes with an administrative prejudice (p. 151.1, 178 of the Criminal Code of Russian Federation, etc.). The nature of the administrative prejudice is an involvement of the person into criminal liability, if the person repeats the act during the certain period after imposing of one or two administrative punishments for the same infraction [Iamasheva, $\mathrm{p}$ 69; Bezverkhov, $\mathrm{p}$ 7]. The intersectional character of such legal phenomenon means a close interaction criminal and administrative law. It is represented that maintenance of enforcement and ensurance of legal means of safe coexistence of people in society are possible only as a result of close interaction of the all branches at all levels and stages of a legal regulation, their constant dynamics and interpenetration to each other. All aforesaid integrative and converting features of prejudices are caused by their inclusion in system 
saving mechanism structure and via performing important role in the process of its functioning both in branch and in intersectional levels.

One more element of system saving mechanism in the criminal law is so-called lacune rule, a doctrinal rule to reveal, overcome and eliminate gaps in the law. In the special literature the necessary conditions for revealing gaps in criminal law are formulated, and also the special algorithm of law enforcement actions are offered as such:

1) it is necessary to know the existing criminal legislation, to be able to be orientated, see communication between the General and Special parts instructions, and also their interdependence and interrelation with norms of other branches of the law;

2) At the same time it is necessary to base on the principles of criminal law, its

objectives, to know the practice of criminal law application, to use legal and doctrinal interpretation of a legal material;

3) it is necessary to appeal to the jurisprudence and special researches on interested questions;

4) it is necessary to reveal the need for a legal mediation of the concrete relations;

5 ) it is necessary to find out a practice of normative regulation of the similar public relations and practice of the individual legal influence in the similar situations;

6) it is necessary to pay attention on compliance of the considered relations to interests of the personality, society, state and on possibility of ensuring its protection with economic, social, political, organizational and other means [Kaufman, p. 237-238].

Thus, the law enforcer for revealing of a gap in the criminal law has to find out lack of regulation of any case in the branch legal sources and to prove the need of a legal regulation of the corresponding relation proving its legal character. We add that the law enforcer has to know not only the criminal legislation, but also to be orientated in other criminal law sources, to realize their interrelations, to understand criminal law system, to be aware of correlations and interdependence of its elements, to be able to predict that the casual completion of the found gap will rather harmoniously fit in the aforesaid system.

It allows us to conclude that lacune rules are necessary in criminal law system not only for "making ready" the subsystems of criminal law and institutions to the existing public relations or for subsystem existence of a criminal law relations or for development of legal consciousness and level improvement of law-enforcer professional competence, but also for associations of all these components in order to observe, reveal and protect the rights of each person in the criminal law sphere in the territory of a certain state and even beyond it. The existence of lacune rules in the system saving mechanism of criminal law, and consequently in branch system provides its optimal and uninterrupted functioning which is vital for the timely decisions for branch objectives and for achievement of the corresponding goals.

The system saving mechanism maintains the balance and the balanced condition of criminal law branch and with the help of socalled "collision" norms, specialized judicial norms, intended for solution between juridical norms. The main feature of these norms is their participation in regulation of the public relations with those judicial norms whose contents appeal to the law enforcer and other participants of legal communication [Tille, p 166; Alekseev, p 241]. At the same time they are relatively independent from the functional mission, because any collision norm regulates actions of a law enforcer through a choice of one of the collision norms in case of a concrete situation. It stands for a sufficient autonomy of these norm groups in legal system and their specific subject of regulation. It also emphasizes their validity and meaning, 
"the greatest powerful beginning" they possess [Vlasenko, p. 51], due to which they are capable to resolve a conflict between judicial norms, to establish an order in implementation of pushing standard instructions and to stabilize legal system and to support its balance state. By the fact of their existence, the collision norms free lawmaking bodies from a further explanation and the subsequent changes collision of judicial norms. But the most important is that they significantly facilitate the law-enforcement activity because they give to law enforcer the reference points of how to behave in a certain case, which judicial norm to choose.

Nowadays, an independent subsystem of collision norms is absent both at branch and at interbranch levels. Some collision instructions can be met in various legal acts: so, in p.p. 2 and 3pt. 2 of the Federal law of June 13, 1996 "On an imposition of the Criminal Code of the Russian Federation" and p. 10 of the Criminal Code of Russian Federation special rules of permission of the temporal collisions between judicial norms and instructions were accepted in different time.

Aforesaid information helps us to conclude that collision norms are an important system saving factor for criminal law branch, admitted as a necessary element of the mechanism specializing on preservation, protecting integrity of legal system (and criminal law system in particular) from any external and internal factors counteracting from normal functioning.

To sum everything up, we note that system saving mechanism in criminal law is a system of the system saving elements, which provide integrity and unity of branch; it is a peculiar structure, the internal device which forces the necessary actions connected to each other, but at the same time mobile elements of criminal law system. This mechanism is necessary for each branch, because without it the law becomes powerless, not capable to perform the functional mission (there will be a disunity of criminal law, their isolation from real needs of legal practice and legal relationship, the quantity of collisions will increase disconnection in the system of legal sources of the law).

Thus, this is one of the most important means of self-governance and self-regulation in the law (and in criminal law in particular).

The elements of the system saving mechanism carry out a particular processing of criminal law material, determine the content and implementation of each criminal precept of law and institution, penetrate all legal sources of this branch of the law, influence emergence and development of criminal legal relations, i.e. support intra-branch unity and coherence in the aforesaid legal phenomena, thereby providing systemacity in criminal law and its branch integrity. The system saving mechanism states, animates and humanizes legal reality with the help of adaptation and innovation of elements of system of criminal law in relation to realities of the modern public relations due to their completion of limited opportunities and corrections leading to the exact setup of mechanisms of criminal law regulation and eliminating defects in branch system. Thus, intersystem and logical contradictions are eliminated in the criminal law contents; the continuity and constancy in the criminal law and perception of progressive provisions in other legal subsystems is provided and also impractical legal instructions are revealed, the ground for modeling and creating legislation future is prepared. 


\section{References}

1. Alekseev, S.S. Problems of the theory of law. Sverdlovsk, 1973. Vol. 2, 401 p.

2. Babaiev, M.M., Pudovochkin, Iu.E. (2012). The principles of criminal law and bases of its sustainable development. Library of the criminalist, 1 (2), 5-16.

3. Bezverkhov, A.G. Administrative prejudgement in criminal law of Russia. Actual problems of criminal law, criminology, criminal and executive law. Samara, 2012. pp. 5-26.

4. Iamasheva, E.V. (2009). On a question of restoration of institute of administrative prejudgement in criminal law of Russia. Magazine of Russian law, 10, pp. 69-79.

5. Inogamova-Khegai, L.V. (2014). Conceptual ideas of reforming the Criminal Code of the Russian Federation. Criminology Journal of Baikal National University of Economics and Law, 1, pp. 84-92.

6. Kaufman, M.A. Gaps in criminal law and judicial discretion. Moscow, 2009. 344 p.

7. Komissarova, Ie.G., Kuznetsova, O.A., Borisevich, G.Ia. (2013). Cross-sectional prejudgement as an economical crime countermeasure. Criminology Journal of Baikal National University of Economics and Law, 3, pp. 90-97.

8. Kozachenko I.Ia. [et al.]. Criminal law. General part. Textbook. Moscow, 2008. 720 p.

9. Kudriavtsev, V.N., Naumov A.V. [et al.] (eds.). Course of Russian criminal law. General part. Moscow, 2001. $767 \mathrm{p}$.

10. Lazarev, V.V. Case decision of the Constitutional Court of Russian Federation (2009). Magazine of Russian law, 6, pp. 114-123.

11. Lopashenko, N.A. Criminal law' influence bases. St. Petersburg, 2004. 338 p.

12. Mal'tsev, V.V. The principles of criminal law. Volgograd, 2001. $266 \mathrm{p}$.

13. Naumov, A.V. Russian criminal law. Course of lectures in 3 v. Moscow, 2011, v.1 General part. $768 \mathrm{p}$.

14. On the case of constitutionality check of p. 1 a.188 of the Criminal Code of Russian Federation in connection with complaint of citizen M.A. Aslamazian: Resolution [passed by the Constitutional Court of Russian Federation on May 27, 2008], Rossiiskaia gazeta. June 7, 2008.

15. Pan'ko, K.K. Fiction in criminal law in the lawmaking sphere and law enforcement. Avtoref. diss. ... k.iu.n. Iaroslavl', 1998. 19 p.

16. Skoblikov, P.A. (2009). Prejudgement of the acts of arbitration courts in criminal trial: new reading. Magazine of Russian law, 2, pp. 69-82.

17. Tille, A.A. Time, space, law. Moscow, 1965, 201 p.

18. Vlasenko, N.A. Conflict norms in Soviet law. Irkutsk, 1984. 100 p.

19. Volkov, K.A. (2013). Police crime counteraction activity: conflict of laws on legal regulation of justifiable defense and criminal custody. Criminology Journal of Baikal National University of Economics and Law, 2, pp. 81-87. 


\section{Системосохраняющий механизм \\ в российском уголовном праве: \\ понятие, структура, значение}

А.В. Денисова

Самарский государственный университет Россия, 443011, Самара, ул. Ак. Павлова, 1

B статье проанализированы особенности функиионирования системосохраняющего механизма в уголовном праве; дана подробная характеристика его структуры и содержания, выявлено значение этого механизма для обеспечения отраслевой целостности. Благодаря этому механизму в уголовно-правовой сфере происходит своеобразная обработка отраслевой системы, обеспечивается необходимое сочленение и гармонизачия ее элементов. Тщательно исследованы такие его структурные элементы, как принципы, цели и задачи уголовного права, отраслевые презумпиии и фикиии, преюдиции, пробельные и коллизионные правила. Сделан вывод, что исследуемый механизм является одним из средств саморегулирования в уголовном праве.

Ключевые слова: системность права, уголовное право, системосохраняюший механизм, принцииьь, иели и задачи уголовного права, отраслевые презумпиии и фикции, преюдиции, пробельные и коллизионные правила.

Научная специальность: 12.00.00 - юридические науки. 